\title{
HUBUNGAN HIPERTENSI DENGAN PENINGKATAN TEKANAN INTRA OKULER DI RUMAH SAKIT IBNU SINA, MAKASSAR
}

\author{
Fadli Sufandy Sidik Rifai*, Sri Irmandha $K^{* *}$,Zulfitriani Murfat*** \\ *Mahasiswa Fakultas Kedokteran Universitas Muslim Indonesia \\ **Dosen Bagian Mata Fakultas Kedokteran Universitas Muslim Indonesia \\ **Dosen Bagian Biokimia Fakultas Kedokteran Universitas Muslim Indonesia
}

\begin{abstract}
Abstrak
Latar belakang: Hipertensi adalah gangguan sistem peredaran darah yang ditandai dengan peningkatan tekanan darah $\geq 140 / 90 \mathrm{mmHg}$. Tekanan darah yang tinggi tersebut dapat mengakibatkan kerusakan struktural dan fungsional pada organ-organ tertentu misalnya jantung, ginjal, otak dan mata.. Kondisi hipertensi menyebabkan meningkatnya retensi natrium. Meningkatnya retensi natrium akan menyebabkan penumpukan cairan di mata yang juga menekan nervus optikus. Hal ini dapat memicu peningkatan tekanan intraokuli akibat menumpuknya cairan dan menyebabkan hilang atau gangguan penglihatan akibat penekanan pada nervus optikus. Tujuan: Penelitian ini bertujuan Untuk mengetahui hubungan antara hipertensi dengan penigkatan tekanan intraokuli di Rumah Sakit Ibnu Sina. Metode: Penelitian ini adalah penelitian deskriptif-analitik dengan studi cross sectional dimana penelitian ini bertujuan untuk mengetahui hubungan antara hipertensi dengan tekanan intraokuli dengan cara observasi dan pengumpulan data dilakukan secara simultan. Analisa data menggunakan uji spearman. Hasil: Dari hasil penelitian ini menunjukkan bahwa dari 50 orang yang menjadi sampel, yang mengalami hipertensi grade 1 dengan tekanan intra okuler yang tidak meningkat sebanyak 17 orang (34\%) dan dengan tekanan intra okuler yang meningkat sebanyak 5 orang (10\%). Sedangkan yang mengalami hipertensi grade 2 dengan tekanan intra okuler yang tidak meningkat sebanyak 7 orang (14\%) dan dengan tekanan intra okuler meningkat sebanyak 21 orang (42\%). menunjukkan bahwa hubungan antara hipertensi dengan peningkatan tekanan intra okuli yang terjadi pada pasien dirumah sakit Ibnu Sina Makassar, diperoleh nilai $p<0,05$ (lebih kecil dari nilai $\alpha=0,05$ ). Kesimpulan: Berdasarkan hasil analisis dan pembahasan penelitian maka diambil kesimpulan bahwa ada hubungan secara statistik antara hipertensi dengan peningkatan tekanan intraokuli di Rumah Sakit Ibnu Sina, Makassar.
\end{abstract}

Kata Kunci: Hipertensi, Tekanan Intra Okuler 


\section{PENDAHULUAN}

\section{Latar Belakang}

Gangguan penglihatan dan kebutaan masih menjadi masalah kesehatan di Indonesia. Berdasarkan hasil survei World Health Organization (WHO), penyebab utama kebutaan tahun 2010 adalah katarak (51\%), glaukoma (8\%), penyakit yang berhubungan dengan degeneratif (5\%), kekeruhan kornea (4\%), diabetes retinopati (1\%), trakhoma (3\%), gangguan refraksi (3\%) dan tidak diketahui penyebabnya (21\%). ${ }^{23}$ Prevalensi nasional glaukoma adalah $0,5 \%$ (berdasarkan keluhan responden). Sebanyak 9 provinsi mempunyai prevalensi glaukoma di atas prevalensi nasional, yaitu Nanggroe Aceh Darussalam, Sumatera Barat, Sumatera Selatan, Kepulauan Riau, DKI Jakarta, Jawa Timur, Nusa Tenggara Barat, Sulawesi Tengah dan Gorontalo. ${ }^{24}$

Glaukoma adalah penyakit saraf optik jangka panjang yang ditandai oleh adanya kerusakan struktur diskus optikus atau serabut saraf retina, kelainan lapangan pandang dan biasanya disertai peningkatan tekanan intraokular. ${ }^{25}$ Hampir 60 juta orang terkena glaukoma. Diperkirakan 3 juta penduduk Indonesia terkena glaukoma dan menjadikan penyakit ini sebagai penyebab utamakebutaanyang dapatdicegah. Glaukoma tidak hanya dapat disebabkan tanpa disertai dengan penyakit lainnya tetapi juga dapat disebabkan oleh penyakit lokal pada mata dan penyakit sistemik. Secara khusus, beberapa studi epidemiologi menunjukkan bahwa tekanan darah sistemik yang tinggi dikaitkan denganadanyasedikitpeninggian TIO. ${ }^{4}$

Pengukuran tekanan intraokuli merupakan hal yang penting pada pemeriksaan mata, karena peningkatan tekanan intraokuli dapat merusak ganglion sel dan berakibat rusaknya papil dan lapangan pandang sehingga menimbulkan kebutaan. Tekanan intraokuli merupakan tekanan yang dihasilkan oleh isi bola mata terhadap dinding bola mata. Tekanan ini dipengaruhi oleh lapisan dinding bola mata dan volume bola mata yang terdiri dari: aqueous humor, corpus vitreous, pembuluh darah intraokuli dan isinya. ${ }^{4}$ Rentang tekanan intraokuler normal adalah $10-21 \mathrm{mmHg} .{ }^{25}$

Hipertensi adalah keadaan dimana peningkatan tekanan darah yang memberi gejala yang akan berlanjut untuk suatu organ target seperti stroke pada otak, penyakit jantung koroner pada pembuluh darah jantung dan ventrikel kiri hipertensi pada otot jantung. ${ }^{9}$ Tiap tahunnya, 7 juta orang meninggal akibat hipertensi. gambaran di tahun 2013 dengan menggunakan unit analisis individu menunjukkan bahwa secara nasional $25,8 \%$ penduduk Indonesia menderita penyakit hipertensi. Jika saat ini penduduk Indonesia sebesar 252.124.458 jiwa maka terdapat 65.048.110 jiwa yang menderita hipertensi. Suatu kondisi yang cukup mengejutkan. Terdapat 13 provinsi yang persentasenya melebihi angka nasional, dengan tertinggi di Provinsi Bangka Belitung (30,9\%) atau secara absolut sebanyak 30,9\% $\mathrm{x} 1.380 .762$ jiwa $=426.655$ jiwa $^{33}$

Berdasarkan penelitian yang dilakukan Christina Magdalena (2006) di Rumah Sakit Umum DR. Soetomo Surabaya, menemukan bahwa penderita yang telah menderita hipertensi $\geq 5$ tahun berisiko mengalami glaukoma sebesar empat kali lebih besar. Kondisihipertensi bukan hanya meningkatkan risiko untuk terjadinya serangan jantung 
atau stroke tetapi juga dapat menyebabkan glaukoma. ${ }^{16}$

Oleh karena tingginya angka prevalensi kebutaan akibat hipertensi yang kemudian dapat berakibat peningkatan tekanan intraokuli, peneliti tertarik untuk meneliti hubungan mengenai hubungan hipertensi yang dapat menyebabkan peningkatan tekanan intraokuli.

\section{Kerangka Teori}

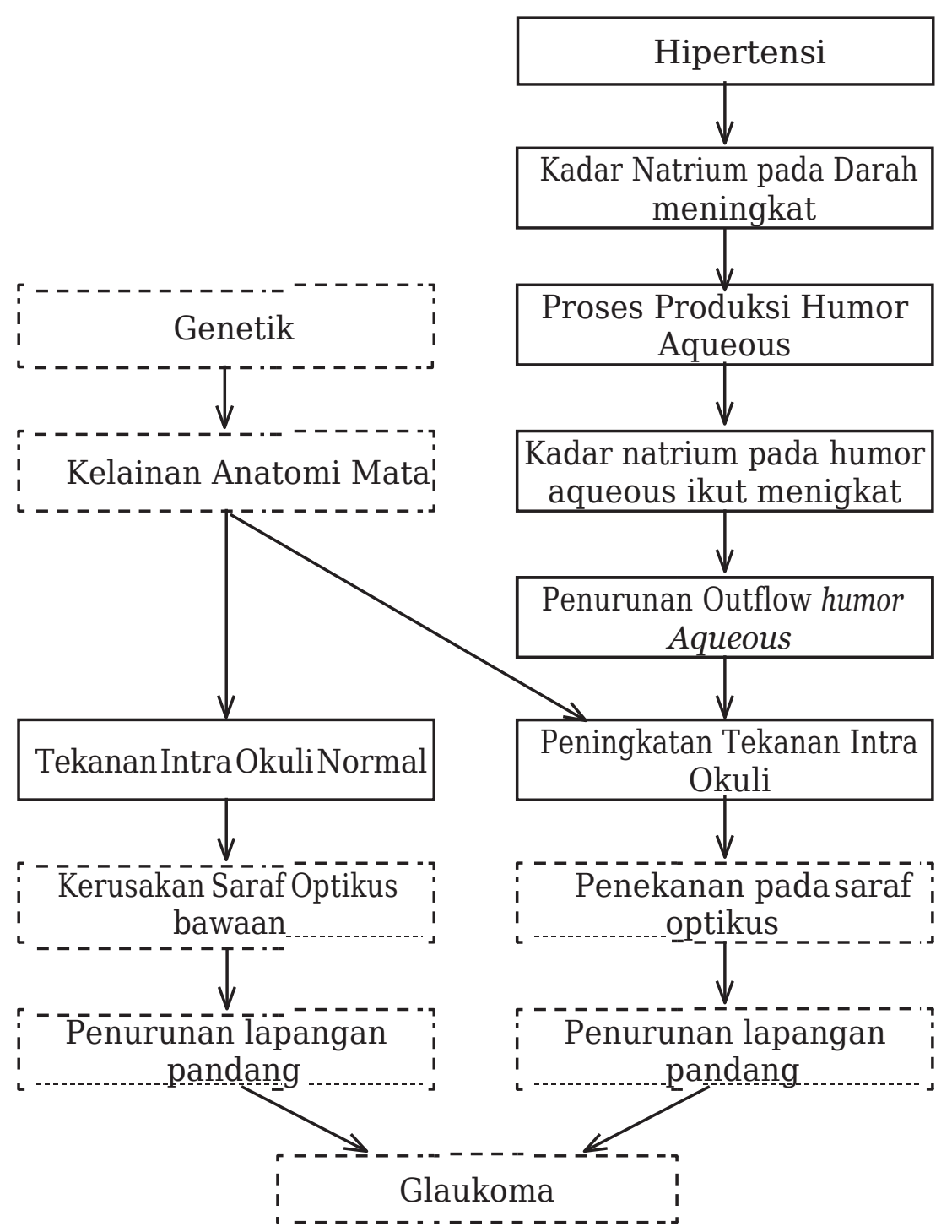

Keterangan:

Variabel yang diteliti

Variabel yang tidak diteliti

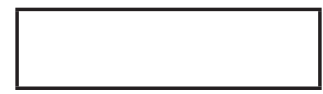

Gambar 2.5 Kerangka Teori 


\section{Kerangka Konsep}

Hipertensi

Keterangan:

Variabel Independen

Variabel Dependen

\section{Peningkatan Tekanan Intraokuli}

Gambar 2.6 Kerangka Konsep

\section{Hipotesis}

a. Hipotesis alternatif $\left(\mathrm{H}_{\mathrm{a}}\right)$ : ada hubungan hipertensi terhadap peningkatan tekanan intra okuli.

b. Hipotesis $\mathrm{Nol}\left(\mathrm{H}_{0}\right)$ : tidak ada hubungan hipertensi terhadap peningkatan tekanan intra okuli.

\section{METODE PENELITIAN Jenis Penelitian}

Penelitian ini adalah penelitian observasi-analitik dengan studi cross sectional dimana penelitian ini bertujuan untuk mengetahui hubungan antara hipertensi dengan tekanan intraokuli dengan cara observasi dan pengumpulan data dilakukan secara simultan atau dalam waktu yang bersamaan (point time approach) ${ }^{20}$.

\section{Lokasi dan Waktu Penelitian}

\section{Lokasi Penelitian}

Penelitian ini dilakukan di Rumah Sakit Ibnu Sina, Makassar.

\section{Waktu Penelitian}

Pengambilan sampel dalam penelitian ini dilaksanakan pada bulan Juni 2017 sampai dengan bulan oktober 2017. Pemilihan waktu penelitian dengan mempertimbangkan keterbatasan waktu, dana dan sumber daya.

\section{Populasi dan Sampel Penelitian} Populasi Penelitian

Populasi target dari penelitian ini adalah seluruh pasien yang mengalami hipertensi pada bulan Juni 2017 sampai dengan bulan Oktober 2017. Populasi terjangkau penelitian ini adalah pasien yang yang mengalami hipertensi di Rumah Sakit Ibnu Sina, Makassar tahun 2017.

\section{Sampel Penelitian}

Sampel penelitian adalah subjek yang diambil dari populasi penelitian yang memenuhi unsur-unsur kriteria inklusi dan tidak memenuhi kriteria eksklusi.

Kriteria Inklusi dan Eksklusi Kriteria Inklusi
a. Pasien hipertensi tingkat I dan II
b. bersedia menjadi sampel penelitian

\section{Kriteria Eksklusi}

a. Pasien dengan glaukoma kongenital dan glaukoma komplikata

b. Pasien katarak

c. Pasien yang memiliki riwayat penyakit sistemikseperti diabetes melitus 


\section{Besar Sampel Penelitian}

Jumlah sampel pada penelitian ini menggunakan metode consecutive sampling, dimana seluruh pasien yang ada pada saat penelitian dan didiagnosa mengalami peningkatan tekanan intraokuli pada bulan Juni 2017 hingga Oktober 2017 di Rumah SakitIbnu Sina, Makassardimasukkan sebagai subjek penelitian pada penelitian ini. Besar sampel ditentukan dengan menggunakan rumus uji korelasi sampel tunggal:

$n=\left[\frac{\left[\left(z_{\alpha}+z_{\beta}\right]\right.}{0,5 \ln [(1+r) /(1-r)]}\right]^{2}+3$

$n=\left[\frac{[(1,960+1,645]}{0,5 \ln [(1+0,5) /(1-0,5)]}\right]^{2}+3$

$n=38$ sampe]

Keterangan:

$n$ =jumlah sampel Minimal

$z_{\alpha}=$ nilai pada distribusi normal standar yang sama dengan tingkat kemaknaan $\alpha$ (untuk $\alpha=0,05$ adalah 1,960)

$z_{\beta}=$ nilai pada distribusi normal standar yang sama dengan kuasa (power) sebesar diinginkan (untuk $\beta=0,05$ adalah 1,645)

$r=$ koefisien korelasi $(0,5)$

Adapun cara pengambilan sampel pada penelitian ini menggunakan teknik pengambilan sampel dilakukan secara consecutive sampling dimana semua sampel yang didapat memenuhi kriteria-kriteria yang telah ditetapkan berdasarkan teori dan pertimbangan paraahli. ${ }^{37}$

Pada penelitianinipeneliti mendapatkan sample sebesar 50 sampel, sesuai dengan rumus sample minimal sejumlah 38 , maka penelitia ini dapa dikatakan valid.

\section{Definisi Operasional}

Hipertensi

1. Definisi Oprasional: pasien dihatankan Hipertensi atau tekanan darah tinggi adalah pasien yang mengalami peningkatan tekanan darah sistolik lebih dari $140 \mathrm{mmHg}$ dan tekanan darah diastolik lebih dari $90 \mathrm{mmHg}$ pada dua kali pengukuran dengan selang waktu lima menit dalam keadaan cukup istirahat/tenang.

2. Hasil Ukur:

Tabel 1. KlasifikasiTekanan Darah pada Orang Dewasa

\begin{tabular}{lcc}
\hline \hline Klasifikasi TD & $\begin{array}{c}\text { TD sistolik } \\
\text { (mmHg) }\end{array}$ & $\begin{array}{c}\text { TD diastolik } \\
\text { (mmHg) }\end{array}$ \\
\cline { 2 - 2 } Normal & $<120$ & $<80$ \\
Prehipertensi & $120-139$ & $80-89$ \\
$\begin{array}{l}\text { Hipertensi } \\
\text { tingkat 1 }\end{array}$ & $140-159$ & $90-99$ \\
$\begin{array}{l}\text { Hipertensi } \\
\text { tingkat 2 }\end{array}$ & $\geq 160$ & $\geq 100$
\end{tabular}

3. Skala Pengukuran:Rasio

\section{Tekanan Intraokuli}

1. Definisi Operasional: Pasien yang dikatakan mengalami peningkatan tekanan intraokular ialah pasien dengan tekanan yang dihasilkan oleh isi bola mata terhadap dinding bola mata meningkat sebesar lebih dari $21 \mathrm{mmHg}$ dengan menggunakan alat Non-contact Tonometri.

2. Hasil Ukur: dikatakan meningkat bila $>21 \mathrm{mmHg}$, normal bila <21 $\mathrm{mmHg}$

3. Skala Pengukuran: Rasio

\section{Metode Pengumpulan Data}

Pengumpulan data dilakukan dengan cara melihat hasil pemeriksaan tenakan darah dan penegakkan diagnosis pengukuran tekanan intraokuli oleh dokter umum, 
dokter yang sedang menjalani program pendidikan dokter spesialis (PPDS) Mata dan dokter spesialis mata Rumah Sakit Ibnu Sina, Makassar. Kemudian peneliti juga harus memperhatikan riwayat penyakit sistemik lainnya seperti diabetes melitus, katarak dan lain-lain untuk mempertimbangkan apakah subjek penelitian memenuhi unsur-unsur kriteria inklusi atau tidak.

\section{Alat Pengumpulan Data}

Data dicari dengan melihat hasil pengukuran takanan darah dengan menggunakan tensi meter dan hasil pengukuran tekanan intraokuli dengan mengunakan Non Contact Tonometri dari pasien.

\section{Pengolahan dan Analisa Data}

Pengolahan data untuk menganalisis hubungan variabel penelitian dilakukan dengan menggunakan perangkat komputer, yaitu menggunakan program SPSS (Statistic Packagefor SocialScience) for windows, yang disajikan dalam bentuk tabel dan diagram. Analisis hubungan variabel berupa uji hipotesis yang dihitung dengan menggunakan kaidah statistik uji korelasi untuk mengetahui sejauh mana kekuatan hubungan indeks massatubuh dengan tekananintraokuli.

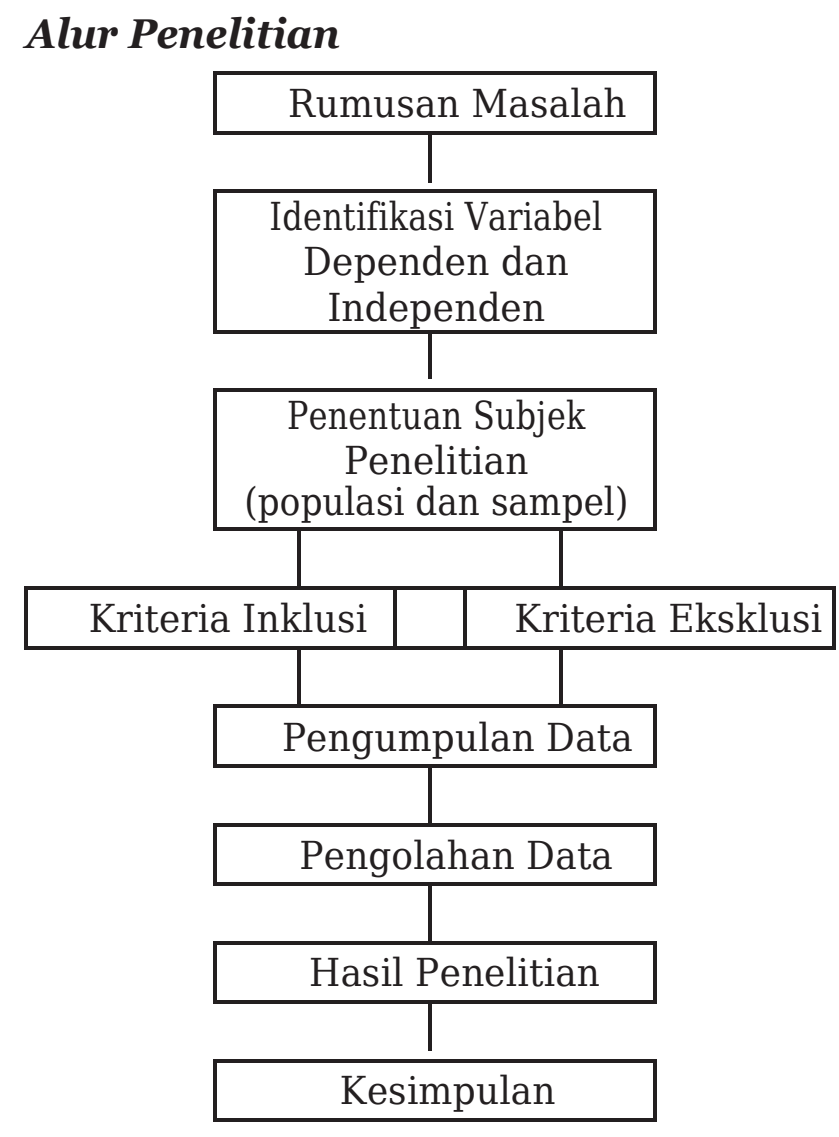

Gambar 3.2 Prosedur Penelitian

HASIL PENELITIAN

Karakteristik Sampel Berdasarkan

Variabel yang Diteliti (Univariat)

Tabel 2. Tekanan Intra Okuler

\begin{tabular}{lcc}
\hline $\begin{array}{l}\text { Tekanan Intra } \\
\text { Okuler }\end{array}$ & Jumlah (n) & $\begin{array}{c}\text { Persentase } \\
\text { (\%) }\end{array}$ \\
\hline \hline Normal & 24 & 48 \\
\hline $\begin{array}{l}\text { Hipertensi } \\
\text { Okuler }\end{array}$ & 26 & 52 \\
Total & $\underline{50}$ & $\underline{\mathbf{1 0 0}}$ \\
\hline
\end{tabular}

Tabel 2. menunjukkan bahwa dari 50 orang yang menjadi sampel, diambil 24 orang (48\%) yang tidak mengalami peningkatan Tekanan intra okuler dan 26 orang (52\%) yang mengalami peningkatan tekanan intra okuler. 


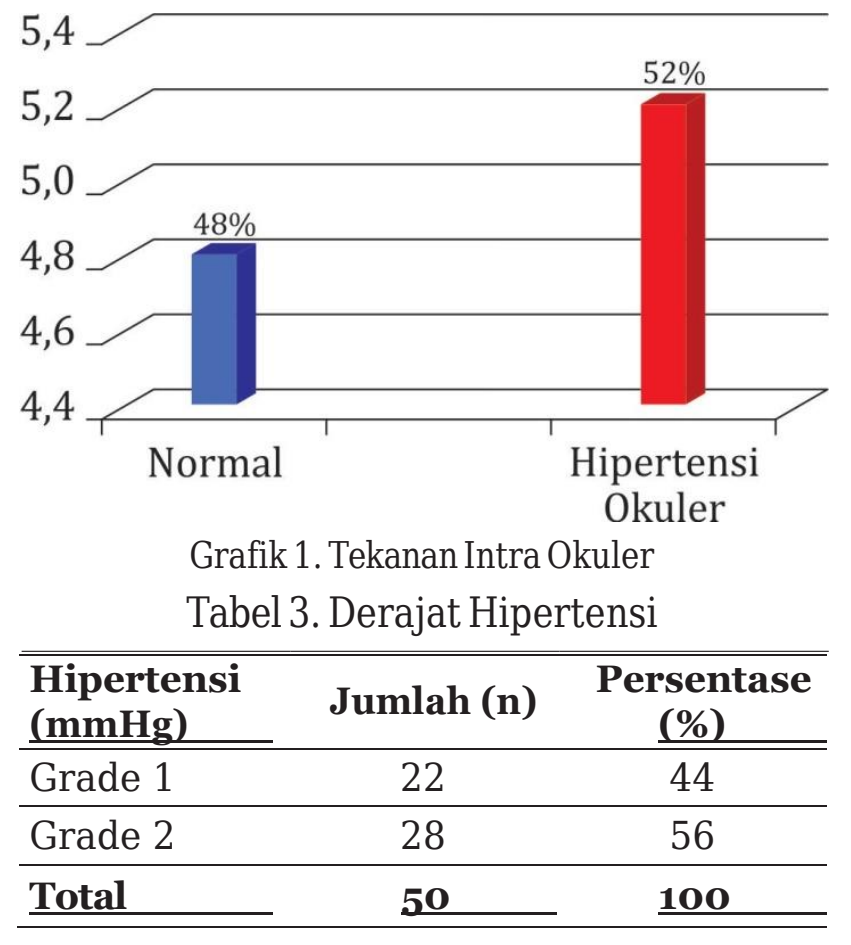

Tabel 3. menunjukkan bahwa dari 50 orang yang menjadi sampel, sebanyak 22 orang (44\%) dengan Hipertensi 1, 28 Orang (56\%) dengan hipertensi grade 2 .

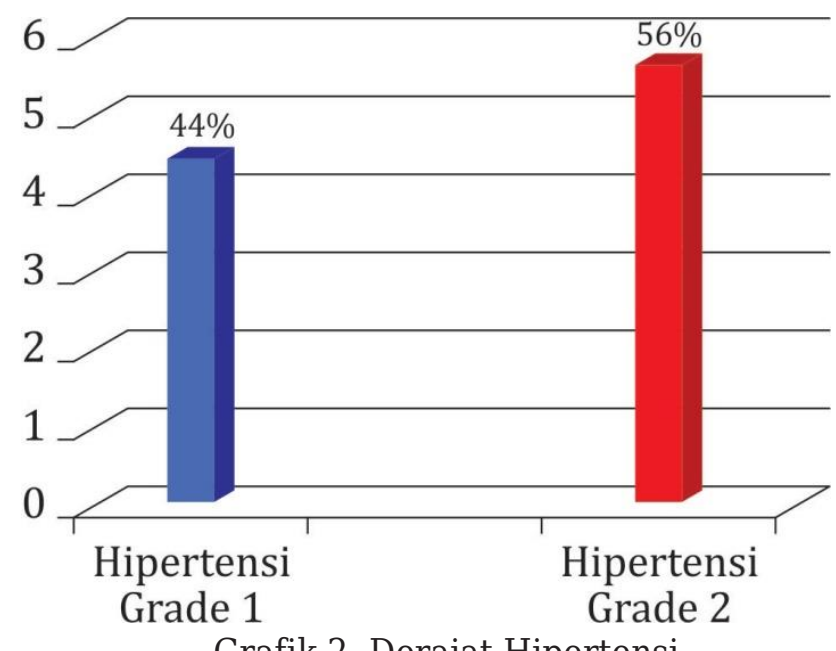

Analisis Hubungan Antara Variabel yang Diteliti (Bivariat)

Tabel 4. Analisis Hipertensi Terhadap Peningkatan Tekanan Intra Okuler

\begin{tabular}{|c|c|c|c|c|c|c|}
\hline & & & \multicolumn{2}{|c|}{ Tekanan Intra Okuler } & \multirow[b]{2}{*}{ Total } & \multirow[b]{2}{*}{$\mathbf{P}$} \\
\hline & & & Normal & $\begin{array}{c}\text { Hipertensi } \\
\text { Okuler }\end{array}$ & & \\
\hline \multirow{4}{*}{ Hipertensi } & \multirow{2}{*}{ Grade 1} & Jumlah & 17 & 5 & 22 & \multirow{6}{*}{$<0,01$} \\
\hline & & Persentasi & $34 \%$ & $10 \%$ & $44 \%$ & \\
\hline & \multirow{2}{*}{ Grade 2} & Jumlah & 7 & 21 & 28 & \\
\hline & & Persentasi & $14 \%$ & $42 \%$ & $56 \%$ & \\
\hline \multirow{2}{*}{\multicolumn{2}{|c|}{ Total }} & Jumlah & 24 & 26 & 50 & \\
\hline & & Persentasi & $48 \%$ & $52 \%$ & $100 \%$ & \\
\hline
\end{tabular}

Sumber: DataPrimer 2017

Uji Spearman

Tabel 4 menunjukkan bahwa dari 50 orang yang menjadi sampel, yang mengalami hipertensi grade 1 dengan tekanan intra okuler yang tidak meningkat sebanyak 17 orang $(34 \%)$ dan dengan tekanan intra okuler yang meningkat sebanyak 5 orang (10\%). Sedangkan yang mengalami hipertensi grade 2 dengan tekanan intra okuler yang tidak meningkat sebanyak 7 orang (14\%) dan dengan tekanan intra okuler meningkat sebanyak 21 orang $(42 \%)$.

Berdasarkanhasilanalisisujihubungan tabel 4. menunjukkan bahwa hubungan antara hipertensi dengan peningkatan tekanan intra okuliyang terjadi pada pasien di rumah sakit Ibnu Sina Makassar, diperoleh nilai $p<0,05$ (lebih kecil dari nilai $\alpha=0,05$ ). 
- Tekanan Intra Okuler tidak Meningkat

Tekanan Intra Okuler Meningkat

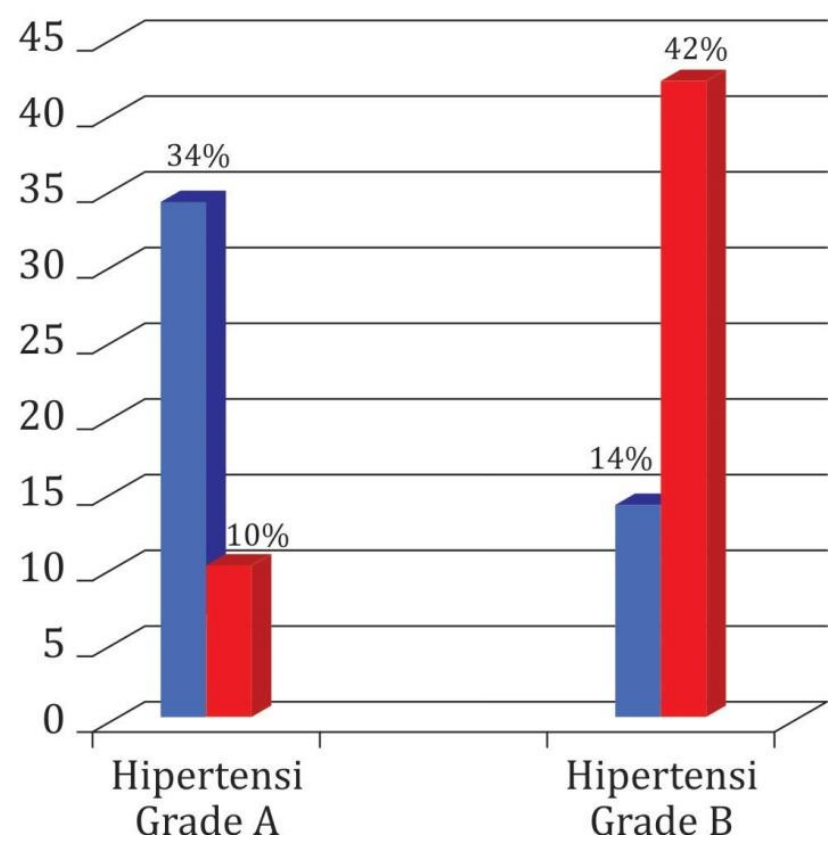

Grafik 3. Persentase Hipertensi terhadap Tekanan intra Okuler

\section{PEMBAHASAN}

Dari hasil penelitian ini menunjukkan bahwa dari 50 orang yang menjadi sampel, yang mengalami hipertensi grade 1 dengan tekanan intra okuler yang tidak meningkat sebanyak 17 orang (34\%) dan dengan tekanan intra okuleryang meningkat sebanyak 5 orang (10\%). Sedangkan yang mengalami hipertensi grade 2 dengan tekanan intra okuler yang tidak meningkat sebanyak 7 orang (14\%) dan dengan tekanan intra okuler meningkat sebanyak 21 orang (42\%).

Sehingga Berdasarkan hasil analisis uji hubungan tabel 5.3. menunjukkan bahwa hubungan antara hipertensi dengan peningkatan tekanan intra okuli yang terjadi pada pasien dirumah sakit Ibnu Sina Makassar, diperoleh nilai $p<0,05$ (lebih kecil dari nilai $\alpha=0,05)$.
Penelitian ini sejalan dengan penelitian yang dilakukan Christina Magdalena tahun 2006 di Rumah Sakit Umum DR. Soetomo Surabaya, menemukan bahwa penderita yang telah menderita hipertensi $\geq 5$ tahun berisiko mengalami glaukoma sebesar empat kali lebih besar. Kondisi hipertensi bukan hanya meningkatkan risiko untuk terjadinya serangan jantung atau stroke tetapi juga dapat menyebabkan peningkatan tekanan intraokuler. ${ }^{16}$

Kondisi hipertensi menyebabkan meningkatnya retensi natrium. Meningkatnya retensi natrium akan menyebabkan penumpukan cairan di mata yang juga menekan nervus optikus. Halinidapat memicu peningkatan tekanan intraokuli akibat menumpuknya cairan dan menyebabkan hilang atau gangguan penglihatan akibat penekanan pada nervus optikus. ${ }^{16}$

Kondisi hipertensi yang diakibatkan oleh perubahan epithelial sodium transport pada distal ginjal dan epitel bersilia yang akhirnya menyebabkan retensi natrium yang berlebihan. Meningkatnya ciliated epithelial sodium transport menyebabkan ekstrusi natrium menuju aqueous humor. Hal ini akan menyebabkan rintangan pada aliran aqueous humor sehingga terjadi penumpukan cairan yang akan menyebabkan peningkatan tekanan intraokuli. ${ }^{16}$

Kondisi peningkatan tekanan darah akan meningkatkan aliran darah pada mata (dengan asumsi bahwa penderita telah mengalami hipertensi dalam jangka waktu yang lama). Setelah peningkatkan tekanan darah berlangsung dalam jangka waktu yang lama, terjadilah kerusakan pembuluh darah kecil dan meningkatnya resistensi aliran dan 
pengurangan dari aliran darah pada mata disertai hilangnya sel-sel ganglion yang akan mengakibatkan penahanan aliran dan terjadi penumpukan cairan sehingga terjadi peningkatan tekanan intraokuli. ${ }^{8}$

\section{KESIMPULAN}

1. Dari 50 orang yang menjadi sampel, diambil 24 orang (48\%) yang tiidak mengalami peningkatan Tekanan intra okuler dan 26 orang (52\%) yang mengalami peningkatan tekanan intra okuler. Serta, dari 50 orang yang menjadi sampel, sebanyak 22 orang (44\%) dengan Hipertensi 1, 28 Orang (56\%) dengan hipertensi grade 2 .

2. dari 50 orang yang menjadi sampel, yang mengalami hipertensi grade 1 dengan tekanan intra okuler yang tidak meningkat sebanyak 17 orang (34\%) dan dengan tekanan intra okuler yang meningkat sebanyak 5 orang (10\%). Sedangkan yang mengalami hipertensi grade 2 dengan tekanan intra okuler yang tidak meningkat sebanyak 7 orang (14\%) dan dengan tekananintra okuler meningkat sebanyak 21 orang (42\%).

3. Berdasarkan hasil analisis uji hubungan dari hasil penelitian, menunjukkan bahwa ada hubungan antara hipertensi dengan peningkatan tekanan intra okuli yang terjadi pada pasien dirumah sakit Ibnu Sina Makassar. Hal ini didapatkan dari nilai $p<0,05$ (lebih kecil dari nilai $\alpha=0,05)$. Sehingga dapat dikatakan bahwa penelitian ini bermakna

\section{DAFTAR PUSTAKA}

1. Bell, J.A., 2012. Primary OpenAngle Glaucoma. Available at: http://emedicine.medscape.com/ article/1206147-overview [Accessed 12 Maret2012]

2. Chopra, V., et al, 2008. Type 2 Diabetes Mellitus and The Risk of Open-Angle Glaucoma. J. Ophtha. 115(2): 227-232. Available at: http://www.researchgate. net/publication/6122768_Type_2_ diabetes_mellitus_and_the_risk_of open_glaucoma_the_Los_Angeles Latino_Eye_Study [Accesed 20 November 2012].

3. Cibis, G.H., Beaver, H.A., Jhons, K., Kaushal, S., Tsai, J.C., and Beretska, J.S., 2007. Trabecular Meshwork. In: Tanaka, S., ed. Fundamentals and Principles of Ophthalmology. Singapore: American Academy of Ophthalmology, 54-59.

4. Costa, V.P., Arcieri, E.S., Harris, A. 2009. Blood Pressure and Glaucoma. Br. J. Ophthalmol 93: 1276-1282.

5. Deokule,S., and Weinreb, R.N., 2008. Relationships among systemic blood pressure, intraocular pressure and open-angle glaucoma. Can J Ophthalmol 43: 302-307.

6. Doshi, A.B., Liu, J.H.K., Weinreb, R.N., 2010. Glaucoma is a $24 / 7$ Disease. In: Schacknow, P.N., Samples, J.R., ed. The Glaucoma Book. USA: Springer, 55-58.

7. Fauci et al, 2008. Harrison's Principle of Internal Medicine. 17th ed. New York: Mc Graw-Hill, 1553-1558.

8. Fraser, S., Wormald R., Hitchings R., 1999. Blood pressure and glaucoma. Moorfields Eye Hospital: 858-859. 
9. Guyton, A.C, and Hall, J.E, 2007. Textbook of Medical Physiology. 11th ed. Philadelphia: Saunders, 220-223

10. Herman, 2009. Prevalensi Kebutaan Akibat Glaukoma di Kabupaten Tapanuli Selatan. Departemen Ilmu Kesehatan Mata, Fakultas Kedokteran Universitas Sumatera Utara, Medan. Available at:http://repository.usu. ac.id/bitstream/123456789/6399/1/ 10E00177.pdf [Accessed 12 Maret 2012].

11. Ilyas, H.S., 2011. Ilmu Penyakit Mata. Edisi Ketiga. Jakarta: Balai Penerbit FKUI, 169-174.

12. Ji,J.D., et al, 2007. Diurnal Variability of Intraocular Pressure. Arch Soc Esp Oftalmol 82: 675-680.

13. Kanski, J.J., 2007. Glaucoma: Primary Open-Angle Glaucoma. In: Edwards, R., ed. Clinical Ophthalmology, A Systemic Approach, Sixth Edition. Philadelphia: Saunders, 382-390.

14. Khurana, A.K., 2007. Comprehensive Ophthalmology.4th ed. New Delhi: New Age International (P) Limited, 205-231.

15. Kwon, Y.H., Fingert, J.H., Kuehn, M.H., Alward, W.L.M., 2009. Mechanisms of Disease, Primary Open-Angle Glaucoma. N EnglJ Med 360: 1113-1124.

16. Langman,M.J.S., Lancashire, R.J., Cheng K.K., Stewart P.M., 2005. Systemic hypertension and glaucoma: mechanisms in common and cooccurrence. Br JOphthalmol 89: 960963.
17. Leske, M.C., etal, 2002. Incident OpenAngleGlaucomaandBloodPressure.Arch Ophthalmol.120(7): 954-959. Available at: archopht.jamanetwork.com/article. aspx?articleid= 271345 \#RESU LT S [Accesed 20 November 2012]

18. Moore, K.L., Dalley, A.F., Agur, A.M.R. 2010. Clinical Oriented Anatomy. 6th ed. Philadelphia: Lippincott Williams \& Wilkins, 895-896.

19. Mukhtar, Z., etal, 2011. Pengertian dan Jenis Data. Desain Penelitian Klinis dan Statistika Kedokteran. Edisi 1. Medan: Usu Press 2011.

20. Notoatmojo, S., 2010. Metode Penelitian Survey: Rancangan Survey Cross Sectional. In: Notoatmodjo, S., ed. Metodologi Penelitian Kesehatan. Jakarta: Rineka Cipta, pp.37-38.

21. Paul R, 2008. Anatomi dan Embriologi Mata: Sudut Bilik Mata Depan. In: Paul R, Whitcher, J.P, ed. Oftalmologi Umum Vaughan\&Asbury. Ed.17. Jakarta: EGC, 12-13.

22. Perdami, 2010. Tentang Glaukoma. Jakarta: Persatuan Dokter mataIndonesia.Availableat:http:// www.perdami.or.id/?page $=$ news seminat.detail\&id=1 [Accessed 12 Maret 2012].

23. World Health Organization. Global Data on Visual Impaiment 2010.

24. Riset Kesehatan Dasar, 2007. Direktorat Jendral Penelitian dan Pengembangan Kesehatan. Available at: http://203.90.70.117/searo/ Ind onesia/L inkFiles/H ealth Information_and_Evidence_for_policy_ Riskesdas_2007.pdf[Accessed 12 Maret 2012]. 
25. Salmon, J.R, 2008. Glaukoma. In: Paul $\mathrm{R}$, Whitcher, J.P, ed. Oftalmologi Umum Vaughan\&Asbury. Ed.17.Jakarta:EGC, 212-224.

26. Sastroasmoro, S., 2007. Pemilihan Subjek Penelitian. In: Sastroasmoro, S., ed. Dasar-Dasar Metodologi Penelitian Klinis.Jakarta: Sagung Seto, 78-91.

27. Simmons, S.T., et al, 2007. Intraocular Pressureand Aqueous Humor Dynamics. In: Tanaka, S., ed. Glaucoma. Singapore: American Academy of Ophthalmology, 17-29.

28. Simmons, S.T., et al, 2007. Introduction to Glaucoma: Terminology, Epidemiology, and Heredity. In: Tanaka, S., ed. Glaucoma. Singapore: American Academy of Ophthalmology, 3-15.

29. Solomon, I.S., 2002. Aqueous Humor Dynamics. Available at: http://www. nyee.edu/pdf/solomonaqhumor.pdf [Accessed 12 Maret 2012].

30. Souza, S.D., 2010. Evaluation of Systemic Hypertension as a Risk Factor for Primary Open Angle Glaucoma. Department of Ophthalmology, St. John's Medical College, Bangalore. Available at:119.82.96.198:8080/ jspui/bitstream/123456789/5827/1/ D’Souza\%20Sharon.pdf[Accesed 20 November 2012].

31. Tumbelaka, A.R., Riono, P., Sastroasmoro S., Wirjodiarjo, M., Pudjiastuti, P., Firman K., 2007. Pemilihan Uji Hipotesis. In: Sastroasmoro, S., ed. Dasar-Dasar Metodologi Penelitian Klinis. Jakarta: Sagung Seto,279-300.
32. Uhm, K.B., et al, 1992. Glaucoma Risk Factors in Primary Open-Angle Glaucoma Patients Compared to Ocular Hypertensives and Control Subjects. Korean J. Ophthalmol 6: 91-99.

33. Victor, R.G., and Kaplan, N.M., 2007. Systemic Hypertension: Mechanisms and Diagnosis. In: Libby's Braunwald's Heart Disease: A Textbook of Cardiovascular Medicine, 8th ed. Philadelphia: Saunders, 1027-1028.

34. Wahyuni, A.S., 2007. Chi Square. In: Statistika Kedokteran (Disertai Aplikasi dengan SPSS). Jakarta: Bamboedoea Communication, 87-102.

35. Walsh, R.A., et al, 2008. Hurst's The Heart. 12th ed. New York: Mc Graw-Hill.

36. Zarei, R., et al, 2011. The Association of Primary Open Angle Glaucoma and Systemic Hypertension in Patients Referred to Farabi Eye Hospital. Iranian. J. Ophthamol 23(2): 31-34. Available at:www.sid.ir/en/VEWSSID/J_ pdf/91120110207.pdf [Accesed 20 November 2012].

37. Wahyuni, A.S., 2007. Chi Square. In: Statistika Kedokteran (Disertai Aplikasi dengan SPSS). Jakarta: Bamboedoea Communication,

87-102 
